\title{
MENAKAR DALIL PRO KONTRA PERNIKAHAN ANAK DARI HASIL BAHTSUL MASAIL NU
}

\author{
Muhammad Saiful Umam
}

\begin{abstract}
Abstrak:
Pernikahan adalah sarana untuk menyatukan dua individu hingga keluarga. Pernikahan juga dianggap sebagai jalan untuk menyempurnakan agama. Dikatakan menyempurnakan agama sebab pernikahan dapat menjadikan tameng kedua mempelai dari terjerembab ke dalam perbuatan maksiat yang berhubungan dengan lawan jenis. Namun akan timbul masalah manakala pernikahan dilakukan di usia-usia dini. Artikel ini membahas pertarungan wacana serta argumentasi dari pihak pro dan kontra atas perubahan batas usia pernikahan anak dari yang semula 16 tahun menjadi 18 tahun bagi perempuan dan 18 tahun menjadi 21 tahun bagi laki-laki menurut sudut kajian hukum Islam. Metode penelitian dalam artikel ini adalah deskriptif kualitatif dengan menggunakan analisis konten. Hasil dari penelitian ini menyebutkan bahwa baik kubu pro maupun kontra sama-sama memiliki dasar yang kuat serta ditopang dalil-dalil yang otoritatif. Namun perbedaan mencolok keduanya terletak dalam prinsip istinbath atau pengambilan hukumnya. Jika kubu kontra berprinsip dengan manhaj qawliy atau tekstual, dan ditopang dengan kaidah figh, dar'ul mafsadah muqaddam ala jalbil maslahat, maka kubu pro menggunakan istinbath manhaj atau pengambilan hukum secara subtansi kemaslahatan serta didukung kaidah hukum al ahkam kulluha raji'atun ila mashalihil 'ibad fi ma'ashihim wa ma'adihim .
\end{abstract}

Kata kunci: Pernikahan anak, istinbath, hukum, fikih.

\section{PENDAHULUAN}

Perkawinan, sebagaimana disebutkan dalam Undang-Undang Nomor 1 Tahun 1974 adalah dimaksudkan untuk membentuk keluarga yang bahagia dan kekal. Salah satu prasyarat untuk membentuk keluarga bahagia adalah jika pasangan telah dianggap dewasa untuk memasuki kehidupan berumah tangga. Oleh karena itu, UU Nomor 1 Tahun 1974 Tentang Perkawinan Pasal 7 Ayat (1) menyebutkan batas usia minimal calon mempelai perempuan adalah 16 tahun, sedangkan laki-laki 19 tahun. Ketentuan tentang batasan usia nikah itu dimaksudkan agar pasangan cukup dewasa untuk memasuki lika-liku kehidupan perkawinan sehingga kehidupan berkeluarga akan lebih tangguh. Di sisi lain, batasan usia perkawinan bisa menjadi cara untuk memberi kesempatan kepada anak-anak untuk mengenyam pendidikan yang memadai sehingga memiliki modal masa depan yang lebih baik dan kuat.

Namun demikian, terdapat perbedaan dalam menentukan batas usia anak antara UU Nomor 1 Tahun 1974 Tentang Perkawinan dengan UU Nomor 23 Tahun 2002 Tentang Perlindungan Anak. UU Nomor 1 Tahun 1974 menetapkan batas usia minimal untuk menikah adalah 16 tahun bagi perempuan dan 19 tahun bagi lakilaki. Dengan demikian di bawah usia tersebut dianggap masih anak-anak dan belum layak menikah. Sementara itu, dalam UU Nomor 23 Tahun 2002 Bab I Ketentuan

\footnotetext{
${ }^{1}$ Institut Agama Islam Negeri Kediri, Email: saifulmu7@gmail.com
} 
Umum Pasal 1 menyatakan bahwa anak adalah seseorang yang berusia di bawah 18 (delapan belas) tahun. Oleh sebab itu, sejumlah aktivis yang terhimpun dalam 18+ melakukan Judicial Review ke Mahkamah Konstitusi untuk menaikkan usia perkawinan menjadi 18 tahun bagi perempuan dan 21 tahun bagi laki-laki ${ }^{2}$

Secara khusus penelitian ini ingin mengungkapkan permasalahan sebagai berikut: (1) Bagaimana metode pengambilan hukum atau istinbath al ahkam yang dipakai kubu pro dan kontra? (2) Apa pijakan dalil yang dipakai oleh kubu pro maupun kontra dalam kasus pernikahan anak? (3) Apa dampak perkawinan di bawah umur? (4) Apa upaya yang dapat dilakukan untuk menanggulangi perkawinan di bawah umur?

Tujuan penelitian adalah untuk memberikan gambaran terkait perkawinan di bawah umur khususnya dalam hal: metode pengambilan hukum yang digunakan kubu pro dan kontra, pijakan dalil yang dipakai oleh kubu pro maupun kontra dalam kasus pernikahan anak, dampak perkawinan di bawah umur bagi pasangan, serta berbagai upaya yang bisa dilakukan untuk menanggulangi perkawinan di bawah umur. Hasil penelitian ini selanjutnya dapat menjadi masukan bagi pejabat Kementerian Agama khususnya Ditjen Bimas Islam terkait dengan pencatatan perkawinan maupun program-prgram keluarga sakinah. Hasil penelitian juga bisa dimanfaatkan oleh instansi lain seperti Kementerian Pemberdayaan Perempuan dan Perlindungan Anak maupun lembaga-lembaga keagamaan Islam yang secara khusus memberi perhatian terhadap masalah perempuan dan anak.

Penelitian ini menggunakan pendekatan kualitatif. Jenis penelitian yang dipilih oleh penulis ini adalah penelitian kepustakaan (library research), karena sumber data yang digunakan adalah seutuhnya berasal dari perpustakaan atau dokumentatif, yakni mengkaji sumber data yang terdiri dari literatur-literatur yang berkaitan dengan tema fikh pernikahan dan perundang-undangan kompilasi hukum Islam. Selanjutnya pengolahan data dalam penelitian ini menggunakan metode deskriptif-analitis, yaitu model penelitian yang berupaya mendeskripsikan, mencatat, menganalisa dan menginterpretasikan kondisi-kondisi yang ada sehingga diharapkan memberi gambaran kepada pemangku kebijakan untuk dapat menentukan kebijakan yang tepat dalam permasalahan batasan usia dalam menjalin perkawinan.

\section{PEMBAHASAN}

\section{Sejarah Bahtsul Masail NU}

Bahtsul masail adalah forum ilmiah yang digunakan untuk mendiskusikan sebuah topik dan mencari hukum atas sebuah permasalahan atau fenomena yang terjadi dalam masyarakat. Dalam sejarahnya, bahtsul masail di kalangan NU diyakini merupakan tradisi intelektual yang berkembang sejak lama, bahkan disinyalir forum

2 Roland and dkk, Fikh Perwalian (Jakarta Selatan: Yayasan Rumah Kita Bersama, 2019), 274. 
ini lahir sebelum NU dibentuk. Martin van Bruinesse ${ }^{3}$ berpendapat bahwa tradisi bahtsul masail yang berkembang di kalangan NU bukanlah murni dari gagasan para kyai-kyai NU. Jauh sebelum bahtsul masail berkembang di kalangan NU, tradisi seperti itu telah ada di Tanah Suci yang disebut dengan tradisi halaqah. Ide bahtsul masail menurutnya adalah tradisi yang diimpor dari Tanah Suci Makkah. Hal itu diperkuat oleh isi anggaran dasar NU pada muktamar NU di Lirboyo Kediri ${ }^{4}$. Berkembangnya tradisi bahtsul masail di kalangan NU bukanlah sesuatu yang mengherankan, sebab hampir seluruh perangkat metodologi dan referensi-referensi (maraji'), serta model halaqah yang digunakan dalam pembahasan bahtsul masail di NU pararel dengan budaya yang terdapat di pondok pesantren.

Sebagai lembaga sosial keagamaan, pesantren tradisional bisa dikatakan senantiasa terlibat aktif dalam dinamika perkembangan masyarakat sekitarnya. Tak ayal kalangan pesantren kerap kali ikut terlibat dalam mengawal dan mengiringi masyarakat dalam segala aspek kehidupan masyarakat. Sulit dipungkiri bahwa tokoh pesantren atau kyai yang merupakan seorang guru sekaligus pengkhotbah dalam kehidupannya sehari-hari hampir tidak pernah sepi dari permintaan sebagian anggota masyarakat yang sedang menghadapi problem atau kemelut untuk memberikan nasehat-nasehat maupun jalan keluar ${ }^{5}$. Baik terkait masalah hukum maupun masalah keagamaan lainnya.

Dalam masalah hukum, mula-mula secara individual fatwa diberikan kepada masyarakat yang membutuhkan khususnya fatwa tentang persoalan yang dihadapi masyarakat saat itu. Karena tuntutan semakin besar, para kyai bertindak secara langsung sebagai penafsir hukum bagi kaum muslimin di sekelilingnya ${ }^{6}$. Pada saat itu ada dua macam fatwa yang dikembangkan oleh ulama' pesantren, ${ }^{7}$ pertama, berupa hukum fiqih untuk melaksanakan perintah dan menjauhi larangan Allah, seperti fatwa tentang bilangan shalat tarawih, tata cara berkirim do'a pada mayat, talqin dan sebagainya. Kedua fatwa yang bersifat preventif yaitu fatwa yang diberikan untuk menjaga kelestarian agama Islam dari intervensi budaya asing atau nilai-nilai agama lain, seperti pengharaman pemakaian celana panjang karena tasabuh dengan non muslim.

Meskipun tidak ada sanksi dan pranata hukum yang ketat, fatwa-fatwa tersebut dijadikan acuan dan ditaati oleh masyarakat yang mencari hukum tentang pengalaman agama sesuai aturan-aturan furu'iyah, atau cabang. Kemudian seluruh kekuatan ulama pesantren tersebut terakomodasi dalam wadah Jam'iyah Nahdlotul

\footnotetext{
${ }^{3}$ Martin van Bruinessen, Kitab Kuning, Pesantren Dan Tarekat: Tradisi-Tradisi Islam Di Indonesia (Bandung: Mizan, 1996), 34.

4 "Anggaran Dasar NU Bab 1 Hasil Muktamar NU Ke XXX" (Lirboyo Kediri, n.d.).

${ }^{5}$ A Hasyim Muzadi, Nahdlatul Ulama Di Tengah Agenda Persoalan Bangsa (Jakarta: :ogos Wacana Ilmu dan Pemikiran, 1999), 9.

${ }^{6}$ Harokho Harikhosi, Kiai Dan Perubhan Sosial (Jakarta: P3M, 1987), 140-41.

${ }^{7}$ Maksum Mahfud, Kebangkitan Para Ulama Dan Bangkitnya Ulama (Surabaya: Yayasan Kesejahteraan Umat, 1982), 204.
} 
Ulama. Dengan adanya itu, maka fatwa individual diubah menjadi fatwa kolektif yang dilaksanakan oleh Syuriah Nahdlatul Ulama', terbukti bahwa Muktamar ke I pada tanggal 13 Rabi'ul Tsani 1345H/21 Oktober 1926 M di Surabaya sudah ada Bahtsul Masail. ${ }^{8}$

Selama bertahun-tahun Bahtsul Masail belum menjadi lembaga yang secara resmi menangani masalah-masalah keagamaan yang dipecahkan oleh ulama' di Dewan Syuri'ah. Kemudian pada waktu Muktamar NU ke XXVII di Pondok Pesantren Al-Munawir Krapyak Yogyakarta pada tanggal 26-29 Rabi'ul Akhir 1410 H/25 sampai 28 November 1989 M, bahwa tim perumus komisi satu masail diniyah yang diketuai oleh Dr. H. Said Agil Munawir. MA mengusulkan kepada pengurus besar Nahdlatul Ulama agar membentuk Lembaga Bahtsul Masail yang bertugas menangani persoalan-persoalan yang tumbuh atau yang muncul dalam organisasi dam kalangan masyarakat pada umumnya. 9 10

Atas dasar usulan tersebut maka, pada tahun 1990 pengurus besar NU mengeluarkan surat keputusan tentang pembentukan Lembaga Bahtsul Masail. Penetapan hukum dari Bahtsul Masail tersebut tidak sekedar memberikan jawaban sesaat terhadap kebutuhan praktis masyarakat, tetapi juga menguraikan argumentasi kritis dan komprehensif. Mereka memandang bahwa forum tersebut akan dipertanggungjawabkan di hadapan Allah SWT. Otoritas penafsiran hukum tersebut adalah menjadi tanggung jawab Lembaga Bahtsul Masail Syuriah NU. Majlis Syuriah NU, pada masa zaman Hadratusy Syaikh KH. Hasyim Asy'ari yakni sejak kepemimpinan KH. Wahab Hasbullah, NU lebih terkonsentrasi pada orientasi politik. ${ }^{11}$

Lembaga Bahtsul Masail merupakan forum yang mempunyai otoritas kewenangan dalam menjawab permasalahan hukum keagamaan yang diajukan oleh warga Nahdlatul Ulama. Karena tugas dan tanggung jawab Lembaga Bahtsul Masail itu menghimpun, membahas dan memecahkan masalah-masalah maudluiyyah waqi'iyyah (masalah yang terjadi di masyarakat) yang harus segera mendaparkan keputusan hukum. Adapun pembentukan dan penghapusan Lembaga ditetapkan oleh permusyawaratan tertinggi pada masing-masing tingkat kepengurusan.

\section{Metode istinbath al-ahkam di tubuh Nahdlatul Ulama}

Istinbath secara bahasa memiliki arti mengeluarkan air dari mata air. Sedangkan secara istilah, istinbath adalah mengeluarkan hukum dari teks dengan mencurahkan kemampuan nalar secara optimal. Menurut Imam al-Syaukani, istinbath adalah

8 (A Aziz Masyhuri, Masalah Keagamaan Hasil Mu'tamar Dan Munas NU 1926 Sampai Dengan 1994 (Surabaya: PPRMI dengan Dinamika Press, 1997).

${ }_{9}^{9}$ Masyhuri, 333.

10 Tim Penyusun, "Permasalahan Dan Jawaban Muktamar NU Ke 28 Di PP Al-Munawir Krapyak Yogyakarta" (Menara Kudus, n.d.), 60.

${ }^{11}$ Mahfud, Kebangkitan Para Ulama Dan Bangkitnya Ulama, 220-221. 
operasionalisasi ijtihad karena dalam berijtihad pasti menggunakan kaidah-kaidah istinbath. ${ }^{12}$ Ini menunjukkan betapa bahtsul masail bukan forum kaleng-kalengan yang bisa dipandang sebelah mata. Tradisi semacam inilah yang terus dilestarikan komunitas pesantren tradisional. Fakta semacam ini menunjukkan bahwa komunitas pesantren juga memiliki tradisi intelektual-ilmiah, meski acapkali pesantren dicap sebagai komunitas kolot dan anti kemajuan.

Manhaj atau metode dalam konteks perumusan hukum berkisar pada tiga hal. Pertama, bayaniy (tekstual), yaitu mengeluarkan dan menetapkan hukum berdasarkan teks al-Quran dan hadis. Kedua, qiyasiy atau ta'liliy yaitu mengeluarkan dan menetapkan hukum berdasarkan illat (legal reason) yang ada pada teks al-Qur'an dan hadis, baik illat manshushah (eksplisit) atau mustanbathah (implisit yang digali oleh mujtahid). Ketiga, istishlahiy, yaitu mengeluarkan dan menetapkan hukum yang mengacu kepada tujuan syariat Islam (maqashid al-syari'ah) yang menekankan kepada tuntutan kemaslahatan yang ada dalam realitas. Kemaslahatan yang dimaksudkan adalah hukum tersebut mendatangkan kemanfaatan dan mencegah kerusakan lahir batin, dunia dan akhirat. Manhaj istishlahiy bisa disebut dengan maqashidiy. Dalil sekunder seperti istihsan, maslahah mursalah, dan 'urf termasuk mengacu kepada maqashid al-syari'ah. ${ }^{13}$

Maqashid al-syari'ah dibagi menjadi tiga, yaitu, primer (dharuriyyat), sekunder (hajiyyat) dan komplementer (tahsiniyyat). Dharuriyyat adalah kebutuhan yang menjadi tegak dan tetapnya kehidupan dalam masyarakat. Kehidupan manusia dapat terganggu dan tidak stabil jika kebutuhan dharuriyyat tidak ada. Dharuriyyat ada lima hal, yaitu: agaman, jiwa, akal, keturunan dan harta. Kedua, hajiyyat yaitu kebutuhan yang berfungsi menghilangkan kesulitan dan kesempitan hidup. Misalnyam rukhshah (dispensasi) yang berfungsi menghilangkan kesulitan, bolehnya berbuka bagi orang sakit dan orang bepergian, bolehnya duduk dalam shalat bagi orang yang sakit dan sebagainya. Ketiga, tahsiniyyat yaitu kebutuhan yang berfungsi menjadikan manusia luhur moralitas dan akhlaknya. Manusia tidak mengalami kesulitan dan kesempitan hidup jika tidak memenuhi kebutuhan ini. Misalnya menutup aurat, memakai pakaian baik ketika masuk masjid, mendekatkan diri kepada Allah dengan ibadah-ibadah sunnah, seperti sedekah, shalat dan puasa sunnah $^{14}$.

Yang patut untuk diketahui bersama ialah, keputusan Bahtsul Masail di lingkungan NU dibuat dalam rangka bermadzhab kepada salah satu dari madzhab empat yang disepakati. KH. Hasyim Asy'ari menganggap bahwa mengikuti salah satu dari empat madzhab Sunni adalah sangat penting. Beliau mengemukakan hal ini dan hal-hal lain dalam muqaddimah al Qanun al Asasi al Nahdlatul Ulama 228.

12 Sutrisno RS, Nalar Figh Gus Mus (Yogyakarta: Mitra Pustaka \& STAIN Jember Press, 2012),

13 Panitia Nasional, “Materi Muktamar Ke-33 Nahdlatul ‘Ulama” (Jakarta, 2015), 20-21.

14 Abdul Zaidan Karim, Al Wajiz Fi Ushul Al Fiqh (Beirut: Muassah Al Risalah, 1987), 378-81. 
(pengatur tehadap aturan-aturan dasar NU). Dalam kitab ini, beliau mencoba memurnikan hukum fiqih dari pendapat-pendapat yang meremehkan argumentasi madzhab-madzhab hukum. Beliau menyatakan bahwa perbedaan pendapat diperkenankan selama masih dalam bingkai syari'ah dan tidak keluar dari ajaranajaran Islam. Beliau menyatakan bahwa:

"Mengikuti salah satu dari empat madzhab Fiqih (Hanafi, Maliki, Syafi'i, dan Hambali) sungguh akan membawa kesejahteraan (maslahah) dan kebaikan yang tidak terhitung, sebab ajaran-ajaran Islam (Syari'ah) tidak dapat dipahami kecuali dengan pemindahan dan pengambilam hukum dengan cara-cara tertentu (istinbath). Pemindahan tidak akan benar dan murni kecuali dengan jalan setiap generasi memperoleh ajaran langsung dari generasi sebelumnya".

KH. Hasyim Asy'ari menyetujui empat madzhab ini berdasarkan integritas mereka dalam menjaga keautentikan ajaran yang diwariskan dari generasi-generasi sebelumnya dalam kitab-kitab yang dikenal dan dibawa oleh orang-orang yang sangat kompetten. ${ }^{15}$ Dengan demikian maka NU dalam memecahkan persoalan hukum harus merujuk kepada kitab-kitab yang dianggap mu'tabaroh (otoritatif) yang ditulis para ulama madzhab empat.

Belakangan, bahtsul masail semakin mengalami penyempurnaan terkait metodologi pengambilan hukumnya. Maka dalam hasil keputusan Muktamar NU ke-31 di Solo pada tahun 2004 menyebutkan bahwa sistem pengambilan hukum dalam NU harus didasarkan pada madzhab baik secara qawliy (tekstual) ataupun manhajiy (metodologis) dengan urutan sebagai berikut:

Pertama, apabila dalam kasus hanya ada satu pendapat dari empat mazhab, maka pendapat tersebut yang digunakan. Kedua, jika terdapat pendapat lebih dari satu, maka langkah berikutnya ialah taqrir jama'iy yaitu memilih salah satu pendapat dengan pertimbangan kemaslahatan atau pendapat yang lebih kuat dan mengikuti kriteria mazhab. Dalam mazhab Syafi'iyah, urutan pendapat yang dijadikan rujukan adalah: (1) Pendapat yang disepakati oleh Imam Nawawi dan alRafi'i (syaikhani); (2) Pendapat yang disampaikan Imam Nawawi; (3) Pendapat yang disampaikan Imam al-Rafi'i; (4) Pendapat yang didukung oleh mayoritas ulama; (5) Pendapat ulama yang terpandai dan pendapat ulama yang wara'. Ketiga, ketika tidak ada pendapat yang mampu menyelesaikan masalah, langkah yang harus diambil adalah ilhaq al masail bi nazhairiha secara jama'i oleh ahlinya dengan memperhatikan mulhaq, mulhaq bih dan wajh al ilhaq oleh para mulhiq yang mempunyai kompetensi. Keempat, dalam kasus yang tidak memungkinkan untuk dilakukan ilhaq maka langkah berikutnya istinbath jama'iy dengan prosedur metode

15 Lathiful Khuluk, Fajar Kebangunan Ulama Biografi KH. Hasyim Asy'ari (Yogyakarta: LKIS, 2000), $55-56$. 
manhajiy oleh ahlinya dengan aplikasi qawaid ushuliyyah oleh orang yang punya kompetensi. ${ }^{16}$

\section{Dinamika Pro dan Kontra}

Permasalahan nikah di bawah umur telah mengalami perdebatan sengit di kalangan Nahdliyyin. Wacana bahwa batas usia perkawinan akan dinaikkan menjadi menjadi 18 tahun bagi perempuan dan 21 tahun bagi laki-laki turut dijadikan pembahasan dalam forum bahtsul masail. Kalangan yang kontra terhadap wacana tersebut memberikan beberapa argumen untuk memperkuat pendapat mereka. Argumen pertama ialah syariat Islam membolehkan menikahkan anak kecil (shaghir, shaghirah) tanpa pembatasan. Kedua, pernikahan adalah hak individu yang menjadi kuasa orang tua dan keluarga (wilayah khashshah) sehingga pemerintah sebagai wali 'am tidak punya wewenang untuk melarang pernikahan (membatasi usia minimal perkawinan). Ketiga, jika akad nikah berlangsung di bawah usia pernikahan maka pernikahan tersebut tetap sah dan tidak dianggap keluar dari perintah penguasa ${ }^{17}$.

Dalil yang menjadi pijakan pendapat di atas disarikan dari kitab-kitab mu'tabar yang berafiliasi kepada ahlus sunnah wa al Jama'ah. Kitab-kitab tersebut di antara lain, hadis yang berbunyi:

$$
\begin{aligned}
& \text { قالت عائشـة: تزوجني رسول الله ص.س لست سنين وبني بي و أنا بنت تسعين, قالت: فقدمنا المدينة } \\
& \text { فوعكت شهرا فوفي شعري جميمة فاتتني أم رومان وأنا علي ارجوحة ومعي صواحبي فصرخت بي فأتيتها و } \\
& \text { ما أدري ماتريد بي فأخذت بيدي فأوقفتني على الباب فقلت هاه هاه حتى ذهب نفسي فأدخلتني بيتا فاذا } \\
& \text { نسوة من الأنصار فقلن على الخير و البركة وعل خير طائر فاسلمتني اليهن فغسلن رأسي واصلحتني فلم } \\
& \text { يرعني الا رسول الله ص.س ضسحى فأسلمتني إليه. } 18
\end{aligned}
$$

Dari teks di atas bisa diidentifikasi bahwa metode yang digunakan dalam pengambilan hukum tersebut menggunakan metode bayaniy yang memahami teks sesuai bunyi teks itu sendiri tanpa melihat tujuan dan subtansi yang terdapat di balik teks. Penggunaan metode istinbath qawliy ini adalah hal yang lazim dalam tradisi bahtsul masail NU, khususnya dalam bahtsul masail diniyyah waqi'iyyah (membahas kasus yang terjadi di masyarakat). Dimana para peserta bahtsul masail mengambil pendapat secara tekstual pada mayoritas Imam mazhab yang memperbolehkan pernikahan usia anak. Peserta tidak menggunakan pendapat Imam Syabramah yang mengharuskan pernikahan sesudah baligh. Metode istinbath qawliy yang diambil oleh peserta bahtsul masail ini masuk dalam kategori taqrir

\footnotetext{
${ }^{16}$ Makmur Jamal, Rezim Gender NU (Yogyakarta: Pustaka Pelajar, 2015), 127.

${ }_{17}$ LBMPWNU, Hasil Bahtsul Masail LBM PWNU Jateng 2013-2018 (Semarang Jawa Tengah: LBM PWNU Jateng, 2018), 104-106.

${ }^{18}$ Imam Muslim, Shahih Muslim (Juz 1) (Surabaya: Al Hidayah, n.d.), 595.
} 
jama'iy, yaitu dengan memilih pendapat yang lebih kuat yang didukung mayoritas ulama.

Istinbath qawliy ini juga kerap dipakai dalam masalah ijbar, seorang wali berhak memaksa anak perempuan menikah sebagaimana fiqh Syafi'iyah yang sudah populer dengan syarat-syarat yang ada, seperti tidak ada permusuhan nyata antara ayah dan putrinya, dinikahkan dengan laki-laki yang sepadan, dinikahkan dengan mahar standar (mahar mitsil), mahar berupa mata uang negara, suami bukan orang yang tidak mampu membayar mahar, tidak dinikahkan dengan orang merepotkan dalam bergaul, seperti orang buta dan kakek yang pikun. Dalam pandangan ini wali adalah pihak yang memahami betul kemaslahatan anak perempuannya sehingga ia memiliki otoritas penuh menikahkan anaknya dengan laki-laki pilihannya, meskipun dianjurkan untuk bermusyawarah dengan anak perempuannya agar tidak melahirkan problem di kemudian hari.

Metode istinbath qawliy yang diterapkan dalam permasalahan di atas tidak lepas dari kultur masyarakat NU yang sudah mengakar sejak di pesantren. Di pesantren, mereka memecahkan masalah dalam forum bahtsul masail yang menggunakan manhaj qawliy, sehingga mereka merasa tidak nyaman atau gamang untuk beralih ke metode istinbath manhaji. Ketidak beranian dan kurangnya keahlian menjadi masalah utama mereka sehingga ada resistensi dari kelompok ini terhadap metode istinbath manhaji. Mereka berkeyakinan bahwa metode istinbath qawliy sudah terbukti kebenarannya dan teruji efektivitasnya sejak zaman dulu hingga sekarang.

Perubahan zaman yang bersifat dinamis harus tunduk terhadap kebenaran teks yang dianggap otoritatif dan absolut. Mereka tidak memberikan ruang dinamisasi dan reformasi untuk menyesuaikan dengan realita sosial yang bergerak secara dinamis. Kelompok ini biasanya mengedepankan sadd al dzari'ah yaitu menutup pintu atau sarana menuju kemaksiatan. Mereka khawatir jika menaikkan usia pernikahan akan menyebabkan perzinahan semakin tidak terkendali. Menurut kubu ini, menikah dalam usia anak lebih baik daripada terjerumus dalam pergaulan bebas yang menghalalkan yang dilarang agama seperti minum-minuman keras, zina, mengkonsumsi obat terlarang dan terlibat beragam kriminalitas lainnya.

Kaedah yang dipedomani mereka ialah "menolak kerusakan dikedepankan daripada mendatangkan kemaslahatan". Langkah preventif lebih dipilih dengan pertimbangan kemaksiatan menjadi utama dan priorotas dari pertimbangan yang lain. Kubu ini merekomendasikan kepada pemerintah untuk mengatur teknologi supaya tidak disalahgunakan untuk kemaksiatan. Perbaikan moral di masyarakat harus menjadi prioritas agendan pemerintah. Ketika kondisi mendesak, orang tua harus menyelamatkan anaknya dengan menikahkan anak sesuai fungsi hak ijbarnya. Perceraian dan problem lainnya semisal ketidaksiapan mental, fisik maupun ekonomi akibat usia yang masih anak-anak yang terjadi setelah pernikahan adalah persoalan 
lain. Poinnya adalah bagaimana anak tidak terlibat dalam perzinahan akibat lingkungan pergaulan dan teknologi yang bebas tanpa kendali.

Adapun yang pro terhadap perubahan batas minimum usia pernikahan mendasarkan paradigma kemaslahatan sebagai pedoman dalam menetapkan hukum. Secara historis, kajian maslahah dimulai dari Imam al-Syafi'i dalam kitab alRisalah yang diletakkan dalam kajian qiyas pada bab 'illah hukum. Meski NU identik dengan Imam Syafi'i yang tidak mempopulerkan konsep maslahah, namun Muktamar NU ke 29 di Cipasung Tasikmalaya pada tahun 1415 H/1994 M memutuskan pandangan NU terhadap maslahah 'ammah dalam konteks kehidupan berbangsa dan bernegara. Maslahah 'ammah yang dimaksudkan dalam putusan Muktamar ini adalah hal yang mengandung kemanfaatan untuk kepentingan umat manusia dan tidak terdapat bahaya di dalamnya, dari kegiatan yang mendatangkan kemanfaatan dan menghindari kerusakan. ${ }^{19}$

Prinsip utama maslahah 'ammah adalah: (1) Memperhatikan terwujudnya kesejahteraan dan kemaslahatan umum dengan mengakomodasi kepentingan semua pihak, (2) memperhatikan peranan warga masyarakat, warga bangsa dan lembaga keagamaan dalam proses perumusan untuk mencapai kemaslahatan umum. Prinsip syura dalam hal ini merupakan langkah strategis yang harus diprioritaskan, (3) kemaslahatan umum dalam bentuk kebijakan atau undang-undang lembaga perwakilan rakyat harus menjadi rujukan yang dipedomani pemerintah sebagai pelaksana yang jujur dan bertanggungjawab, (4) kemaslahatan rakyat diwujudkan dan harus memberikan dukungan positif dan kontrol kritis secara berkesinambungan terhadap lembaga perwakilan sebagai perumus (legislatif), lembaga pemerintahan sebagai pelaksana (eksekutif) dan lembaga peradilan (yudikatif), (5) kemaslahatan umum tidak boleh menimbulkan kerugian orang lain atau sekurang-kurangnya memperkecil kerugian yang mungkin lahir karena usaha menghindari kerusakan harus dikedepankan daripada mendatangkan kemaslahatan. ${ }^{20}$ Dengan prinsip semacam itu kemudian mereka memperkuat argumentasi dengan bekal dalil teks seperti di bawah ini:

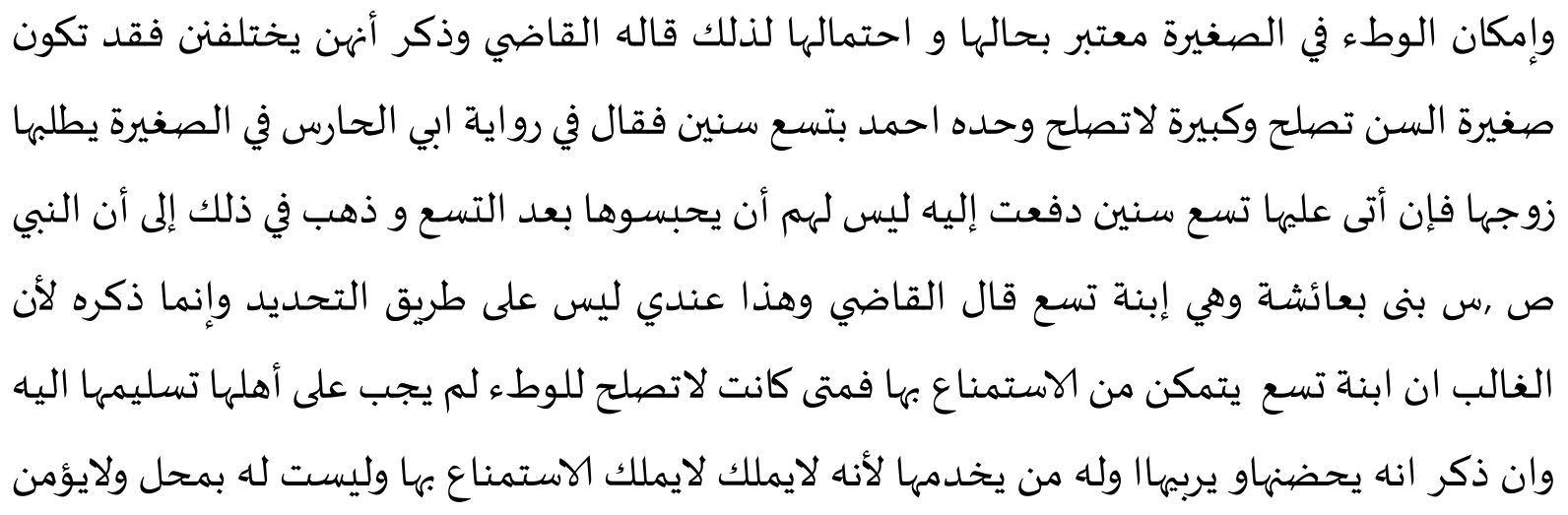

19 Roland, dkk, Fikh Perwalian, 300.
20 Jamal, Rezim Gender NU, 166-68. 


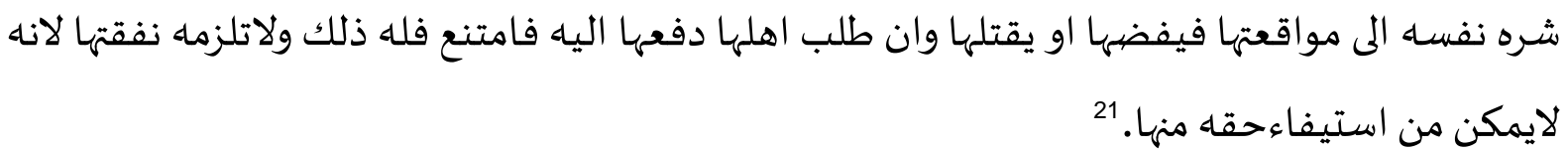

Metode yang digunakan oleh kalangan pro peningkatan batas minimum usia perkawinan ialah metode istinbath manhajiy yang menggunakan kaidah fikh dan ushul fikih untuk menjawab problematika sosial. Metode istinbath manhajiy adalah manhaj istishlahiy atau maqashidiy yang menjadikan kemaslahatan subtansial sebagai landasan hukum tanpa mengabaikan teks yang ada. Mereka berpendapat bahwa pemerintah mempunyai tanggungjawab serta otoritas untuk membuat kebijakan yang mengarah kepada kemaslahatan umum dan demi kemajuan bangsa di masa mendatang.

Landasan tersebut sesuai dengan kaidah yang berbunyi, "kebijakan pemimpin atas rakyatnya bertumpu pada kemaslahatan publik". Istinbath manhajiy dipilih agar dapat menghindarkan dampak negatif yang ditimbulkan oleh pernikahan usia anak. Dampak negatif yang dimaksud antara lain hilangnya usia produktif untuk membekali diri mereka dengan pendidikan yang cukup. Jika itu terjadi maka masa depan bangsa bisa terancam sisi kompetitif dan produktifitasnya.

Kedepan, jika pemerintah tidak menaikkan batas usia menikah maka tingkat sumber daya manusia Indonesia akan tertinggal di bawah negara-negara maju yang telah menaikkan usia menikah. Dalam konteks keluarga, menikah di usia matang akan mengantarkan keluarga menjadi sakinah, mawaddah dan rahmah. ${ }^{22}$ Dalam konteks kehidupan bernegara, menikah di usia dewasa akan melahirkan generasigenerasi yang unggul sebab akan ditopang oleh iklim keluarga yang kokoh dari segi emosional, sosial, intelektual serta ekonomi.

Metode istinbath manhajiy semacam ini memiliki akar yang kuat baik dari tinjauan teks agama maupun tinjauan sosial. Sebagai contoh, negara-negara di Timur Tengah yang mayoritas beragama Islam pun telah membatasi usia pernikahan demi kemaslahatan bangsanya. Hal ini mengindikasikan bahwa di zaman modern yang kompetitif semacam ini dibutuhkan upaya serius untuk pendalaman skill dan pengetahuan di masa muda seseorang, mengingat persaingan dan tuntutan di zaman ini sedemikian kompleks. Sebuah pepatah berbunyi, apa saja yang tidak matang pastilah tidak memiliki kualitas yang maksimal.

Bagi kalangan yang menyetujui wacana ini, mereka bependapat bahwa fikh ialah bersifat temporer atau punya dimensi ruang dan waktu tertentu. Jika di masa lalu tidak ada pembatasan usia pernikahan maka bisa jadi ialah kemaslahatan di era itu. Para ulama fikh di antaranya Imam Syafi'i juga menganjurkan wali untuk menikahkan anaknya setelah baligh. inti dari landasan argumen tersebut ialah pada kemaslahatan. Sebab terdapat kaidah yang berbunyi:

\footnotetext{
${ }^{21}$ Al Mughniy Syarh Al Kabir, “Juz 7,” n.d., 199-200.

22 Roland, dkk, Fikh Perwalian, 303.
} 


$$
\text { الأحكام كلها راجعة إلى مصالح العباد في معاشهم و معادهم }
$$

"hukum harus berorientasi pada kemaslahatan manusia". Kemaslahatan yang dimaksud adalah kematangan fisik, mental, intelektualm sosial dan ekonomi. Sebab dengan modal tersebut akan bisa menghasilkan penerus-penerus bangsa yang berkualitas tinggi dan bisa memiliki daya saing internasional.

Sedangkan permasalahan-permasalahan seperti terjebak dalam pergaulan bebas dan sejenisnya, maka menikah bukanlah solusi utama. Solusi terbaik adalah dengan memberikan edukasi, motivasi dan penyadaran terhadap pentingnya nilainilai agama. Sebab pernikahan bukan sekedar penyaluran hasrat biologi, ia menuntut kesiapan yang matang dalam banyak aspek. Faktanya, pernikahan yang didahului hal-hal yang dilarang agama serta ketidak siapan dalam aspek-aspek yang telah disebut di atas, kerap berujung pada perceraian, kekerasan rumah tangga, aborsi dan hal-hal negatif lainnya.

\section{PENUTUP}

Dari runcingnya perdebatan dua kutub yang berlawanan di atas, kita bisa menarik kesimpulan bahwa ada beberapa opsi dalam istinbath al hukmi, penggalian hukum. Ada yang menggunakan metode qawliy (tekstual) serta ada yang menggunakan metode manhajiy (subtansi kemaslahatan). Metode yang relevan adalah metode yang mampu menjawab problematika zaman. Di mana seseorang dituntut untuk mengkaji dan mendalami pemikiran madzhabnya lalu memahami subtansi dan tujuan pemikiran mazhabnya tersebut. Yang tidak kalah penting, para ahli hukum juga harus memiliki pemahaman pada realitas secara obyektif. Maka dalam hal ini disiplin ilmu ushul fikih harus benar-benar dikuasai. Penguasaan tersebut jangan sampai hanya berhenti pada tataran pemahaman melainkan juga harus diwujudkan dalam tataran pelaksanaan. Praktik ushul fikih menjadi keniscayaan agar fikih tidak jumud atau stagnan, ia harus mampu berdialektika dan merespons dinamika zaman yang dinamis. Semua sumber hukum baik yang disepakati maupun yang tidak disepakati harus dikaji dan dimatangkan. Orientasi dari hal itu adalah agar kajian ushul fikih benar-benar mampu melahirkan problem solving atas kebutuhan dan tuntutan zaman yang selalu berubah dan berkembang. 


\section{DAFTAR RUJUKAN}

“Anggaran Dasar NU Bab 1 Hasil Muktamar NU Ke XXX." Lirboyo Kediri, n.d.

Bruinessen, Martin van. Kitab Kuning, Pesantren Dan Tarekat: Tradisi-Tradisi Islam Di Indonesia. Bandung: Mizan, 1996.

Harikhosi, Harokho. Kiai Dan Perubhan Sosial. Jakarta: P3M, 1987.

Jamal, Makmur. No TitleRezim Gender NU. Yogyakarta: Pustaka Pelajar, 2015.

Kabir, Al Mughniy Syarh Al. “Juz 7,” n.d.

Karim, Abdul Zaidan. Al Wajiz Fi Ushul Al Fiqh. Beirut: Muassah Al Risalah, 1987.

Khuluk, Lathiful. Fajar Kebangunan Ulama Biografi KH. Hasyim Asy'ari. Yogyakarta: LKIS, 2000.

LBMPWNU. Hasil Bahtsul Masail LBM PWNU Jateng 2013-2018. Semarang Jawa Tengah: LBM PWNU Jateng, 2018.

Mahfud, Maksum. Kebangkitan Para Ulama Dan Bangkitnya Ulama. Surabaya: Yayasan Kesejahteraan Umat, 1982.

Masyhuri, A Aziz. Masalah Keagamaan Hasil Mu'tamar Dan Munas NU 1926 Sampai Dengan 1994. Surabaya: PPRMI dengan Dinamika Press, 1997.

Muslim, Imam. Shahih Muslim (Juz 1). Surabaya: Al Hidayah, n.d.

Muzadi, A Hasyim. Nahdlatul Ulama Di Tengah Agenda Persoalan Bangsa. Jakarta: :ogos Wacana Ilmu dan Pemikiran, 1999.

Panitia Nasional. “Materi Muktamar Ke-33 Nahdlatul ‘Ulama.” Jakarta, 2015.

Roland, and dkk. Fikh Perwalian. Jakarta Selatan: Yayasan Rumah Kita Bersama, 2019.

Sutrisno RS. Nalar Figh Gus Mus. Yogyakarta: Mitra Pustaka \& STAIN Jember Press, 2012.

Tim Penyusun. "Permasalahan Dan Jawaban Muktamar NU Ke 28 Di PP AlMunawir Krapyak Yogyakarta." Menara Kudus, n.d. 